\title{
Policies and Variables affecting FDI: A Panel Data Analysis of North African Countries
}

\author{
Ahmed MUSABEH ${ }^{1}{ }^{\oplus}$, Mehdi ZOUAOUI² ${ }^{\circledR}$
}

\begin{abstract}
North Africa region is one of the wealthiest areas due to its natural resources and strategic location. But, it is still fragile according to economic indicators, especially investment environment and foreign direct investment, "FDI", which represents a considerable challenge for governments and policymakers in these countries. This study investigates the main variables and policies that affect FDI inflows and evaluates the effectiveness of these policies on attracting FDI inflows in five North African countries, namely Algeria, Egypt, Libya, Morocco, and Tunisia. To achieve that aim, a panel data of North Africa countries is used within the timeframe of 1996 to 2013, the study has adopted three types of FDI related variables that may affect host country attractiveness: economic variables, institutional variables, and political variables. Also, we have investigated the influence of two kinds of investment policies on FDl: domestic FDI policies, and international FDI policies. The results indicate that the trade liberalization policies and integration into global business have a positive and significant correlation with FDI inflows growth. Additionally, the study also found that increasing domestic investment in host countries attracts more FDI. and adopting more efficient investment policies (investment freedom policies) are statistically significant and have a positive impact on FDI inflows growth in the North Africa region.
\end{abstract}

Keywords: Inward FDI, North Africa, investment policies, trade openness, panel data analysis

Jel Code: F14, F21, F3

\section{DOI: 10.26650/JEPR635016}

${ }^{1}$ Dr., Kadir Has University, Istanbul, Turkey ${ }^{2}$ Istanbul University, Department of International Relations, Istanbul, Turkey

ORCID: A.M. 0000-0003-2923-6204;

M.Z. 0000-0001-9700-2691

\section{Corresponding author/Sorumlu yazar:} Ahmed MUSABEH,

Kadir Has University, Istanbul, Turkey

E-mail/E-posta: ahmedmusabeh88@gmail.com

Submitted/Başvuru: 20.10.2019

Revision Requested/Revizyon Talebi: 02.12.2019

Last Revision Received/Son Revizyon: 27.12.2019

Accepted/Kabul: 28.12.2019

Citation/Atıf: Musabeh, A., Zouaoui, M. (2020). Policies and variables affecting FDI: A panel data analysis of North African Countries. Iktisat Politikası Araştırmaları Dergisi - Journal of Economic Policy Researches, 7(1), 1-20. https://doi.org/10.26650/JEPR635016 


\section{Introduction}

In the last three centuries, several changes had occurred in the structure of the global economy, especially with the appearance of globalization and financial liberalization. These changes have made the flows of foreign investments between countries a vital element in economic development through supporting productivity, disseminating technology between countries, creating job opportunities, improving trade and accelerating growth and development (Asiedu,2006; Pradhan et al.2017). In this regard, FDI flows are considered one of the primary sources of capital flows that have played a crucial role in increasing development and economic growth through its role to enhance the resource transfer effects, which include capital transfer, technology transfer, and management transfer. Thus, and as a result of spillovers of FDI, governments in developing countries motivated to look for bestpractice policies towards FDI, and they strived to be more liberalized to gain the confidence of investors (Te Velde, 2001). According to Dunning (2002) developing countries need to attract FDI from more developed industrialized nations which seek complementary knowledge, intensive resource, and capabilities. As a result of this, the developing countries need to build supportive transparent commercial and legal communication infrastructure in addition to favorable government policies to streamline globalization and innovation.

Consequently, governments in developing countries started to implement a wide range of policies that can achieve a stable environment for investors to support them in carrying out their businesses without incurring avoidable risks. But even though the importance of FDI and its role in economic growth, it remains a controversial point among economists especially with regard to its impact on host country. Within that, an extensive number of empirical studies in the last two decades investigated the relationship between FDI and economic growth. For example, many studies including Koojaroenprasit (2012), Pradhan et al. (2017) were concerned with the examination of the relationship between FDI and economic growth. The findings showed that there is strong and positive relationship between FDI and economic growth. Conversely, the number of studies including Mah (2010), Marc (2011) have found that FDI does not necessarily lead to higher economic growth. And, regarding FDI studies in MENA countries and the Arab world, there are limited studies that touched on policies and variables affecting FDI in this region, and the empirical evidence about their impact on FDI has not been fully fathomed yet. For instance, Onyeiwu (2004), Laabas \& Abdalmoulah (2009) studied the FDI determinants on MENA and they found that a weak infrastructure hurts FDI. Furthermore, some studies including Mina (2007) found that institutional quality and infrastructure development have a significant influence on FDI inflows but, contrary to expectations, stable macroeconomic policies are not sufficient conditions to attract FDI in MENA countries. Other studies done by Mohamed \& Sidiropoulos (2010) examined the determinants of FDI inflows in the MENA region, 
revealed that the existence of a strong financial system and remove trade barriers tare important elements for attracting FDI.

However, few studies dealt with the evaluation of governmental investment policies and its role to attract FDI as well as determinants of FDI inflows in North Africa countries separately and deeply. Thus, this paper intends to have a closer look and stand on the mechanism of attracting foreign investment and examines the determinants of FDI inflows to this region.

In this context, the present research is designed to investigate the main policies and variables that have an effect on FDI inflows in the North Africa region using panel data regression covering the period 1996-2013. The second section of this paper presents an overview of the North African economy and FDI trend during the last 20 years, and the third section presents a brief review of literature of policies and variables related to attracting FDI. The third section sheds lights on the main literature on FDI policies and variables. The fourth section investigates the main policies and variables affecting FDI using panel data regression, and finally the fifth section provides results and a conclusion of the study.

\section{FDI Inflows Trend in North Africa in the last twenty years}

The trend of FDI inflows in this region shows a significant fluctuation in the last twenty years where the amount of FDI flows into North Africa countries have raised from an annual average of US \$ 2.2 billion during the 1990s to US\$ 12.5 billion during the 2000 s and reached its peak in 2007 at US \$ 23.1 billion. As shown in figure 1, FDI flows into North Africa reached its peak in 2007 with $4.5 \%$ of the region's GDP. However, the level of FDI inflows notably decreased in 2011 by $1.5 \%$ of GDP due to political disturbances (the Arab Spring) to reach an annual average of $2 \%$ from 2011 to 2015.

\section{Figure 1. Trend of FDI inflow as \% of GDP in North Africa region 1996-2017}

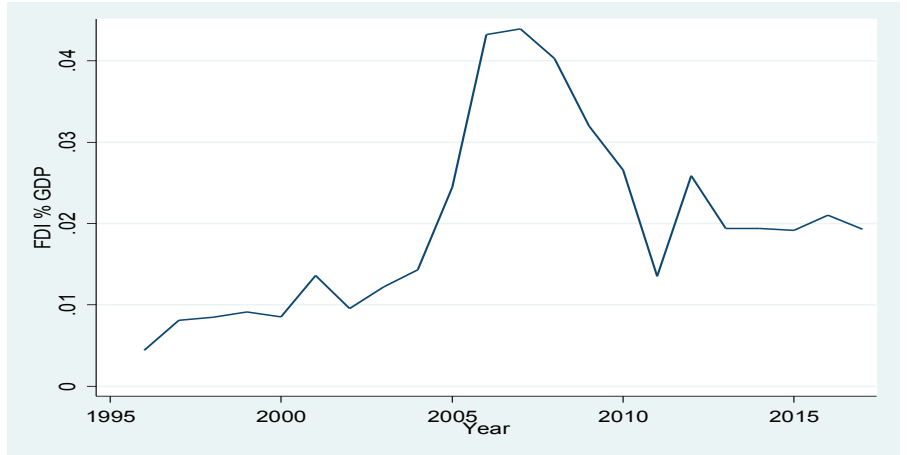

Source: World Investment Report, UNCTAD, (2018) 
Despite the previous indicators, an increasing rate is still emerging compared to what North Africa countries have had from natural resource and geographic location. Interestingly, it is still meager in respect to FDI inward stock as a percentage of GDP. For example, the average of FDI inflow stock over GDP (1996-2013) in the North Africa region was $25.7 \%$ compared $47.3 \%$ in the Southern Africa region, and $49.7 \%$ in South-East Asia.

\section{Literature Review for Determinants of FDI Inflows}

In order to attract FDI, it became imperative for policymakers in host countries to identify the policies and variables that influence the FDI. Consequently, a lot of studies have been conducted in this regard which have the potential of helping policymakers understand the scale and direction of FDI flows. According to Dunning (2002), developing countries need to attract FDI from developed industrialized nations which seek complementary knowledge, intensive resource, and capabilities. As a result, developing countries need to build supportive transparent commercial and legal communication infrastructures along with favorable government policies to streamline globalization and innovation. This brings us to the three main types of variables that can affect FDI flows into host country (economic variables, institutional variables, and political variables) with two kinds of investment policies that may have effects directly on FDI (Domestic FDI policies, and International FDI policies).

\subsection{Economic variables}

In terms of economic variables, the governments in the host countries must effectively manage the policies related to economic variables to increase locational advantage by improving the economic fundamentals (Young et al,2017). According to Wang et al (2012), the location theory provided explanations for the reasons behind the choice of the host country for overseas investment and explained why globally successful industries emerge in specific countries. These explanations depended on the variances among nations concerning access to local markets, availability of comparatively cheap factors of production such as natural resource, and labor force. According to Buettner and Ruf (2007), the location theory of FDI is also concerned with the behavior of the government in the host country towards improving the investment environment through offering investment incentives and strengthening the legal framework.

An extensive range of studies including Mottaleb and Kalirajan (2010), and Abbott et al. (2012) mentioned that the host country's government must pay attention to the overall economic policies. This include specific measurements like market size, natural resources, quality of human capital, infrastructure quality, exchange rate stability, and inflation rate. In terms of variables selection, the study employs the following variables and policies which are classified as a main factor effect on FDI inflows. 
Market size: is seen as one of the vital factors that affect the flows of FDI, where a large current market or increasing expected market size creates more investment opportunities and profits. An extensive number of studies including Asiedu (2006), Boateng et al. (2015) concluded that foreign firms move to countries with broader markets and with higher purchasing powers. This study will use the natural logarithm of real GDP as proxy for market size. The expected sign of the estimated coefficient of market size is positive.

Trade liberalization: The relationship between the host country's openness to trade and FDI inflows is heavily influenced by the goals of these firms from a trade perspective. For example, if the investment aims mainly to be an export-oriented policy, this encourages businesses (vertical FDI flows) to expand in countries with high degree of openness. On the other hand, according to the tariff-jumping hypothesis, foreign firms (horizontal FDI) that aim to serve the local market prefer less openness to enhance their marketplace and to be protected from imports of competitors. While, the resource-seeking FDI, which is the main aim of expansion in the host country, is to reduce production costs.

Therefore, this type of FDI is more concerned about trade cost, and consequently; countries that pursue an open trade policy are more attracted to this kind of investment (Dunning, 1993).

Based on empirical studies, many studies such as Bilel \& Mouldi (2011), and Guris \& Gozgor (2015) concluded that the countries with more trade liberalization could attract more FDI inflows. This study uses the ratio of export plus import over GDP as a proxy for trade openness. The expected result is a positive or negative sign of coefficient concerning FDI.

Natural resources: is considered as an essential locational advantage, many studies including Mina (2007), Poelhekke \& Van der (2013) pointed out that the countries with fewer resources might be more successful in attracting FDI than those nations with a wealth of resources. The idea behind this adverse effect is "resource curse" where the abundant natural resources may create opportunities for rent-seeking behavior and reduce the transparency in resource sales and revenue spending. Regarding the literature review concerned with the effect of the natural resource on FDI, several studies including Asiedu (2004), Yimer (2017) and Yang et al..( 2017) concluded that attracting FDI to the host countries is improved by the availability of natural resources. In contrast, the study of Poelhekke and Ploeg (2013) indicated that the availability of natural resources discourages foreign investment to expand theirs. Our study employs a dummy variable for the countries that have natural resource rent more than $10 \%$ of GDP. The expected effect of the natural resource on FDI is to be negative/ positive. 
Infrastructure development: which is seen as a fundamental element in encouraging FDI as it can contribute to reduce the entering cost (such as transportation costs, and electricity costs) and increase the rate of return on private investment and attract more FDI (Bellak et al.,2009). A series of studies, asghar et al (2011),Choi and Shoham (2016), Kaur et al., (2016) indicated that FDI inflows is positively associated with infrastructure development. This study will use electric power transmission and distribution losses (\% of output) to measure the infrastructure quality. And the result is expected to be a negative sign of coefficient concerning FDI (Asiedu, 2004; Banerjee et al. ,2006).

Stability of Macroeconomic indicators: also plays an essential role in FDI attractiveness, especially when a foreign firm decides to invest abroad. These indicators involve exchange rate stability index and inflation ratio where the stability of these indicators reflects a high degree of certainty. A high rate of inflation is taken to be a sign of internal economic instability in the host country, whereas price instability indicates that the government has shortcomings to conduct appropriate monetary policy. Many studies including Asiedu (2006), Hailu (2010) and Boateng et al. (2015) showed that the inflation negatively affects FDI and a low volume of inflation is likely to attract more inward FDI in developing countries. This study employs the annual percentage change in Consumer Price Index (CPI) as the proxy for the inflation rate. The expected sign of the estimated coefficient of inflation is negative. Many studies including Abbott et al. (2012) mentioned the desire of foreign firms to invest abroad increase when the exchange rate in the host country is stable. Thus, to attract FDI inflows the government in the host country should reduce the fluctuations in exchange rates. This paper also employs the exchange rate stability index as a proxy of exchange rate stability, with the expectation of positive sign of coefficient concerning FDI.

Gross fixed capital formation: several studies including Adhikary (2010), Dash and Sahoo (2010), Feeny et al (2014) confirmed that enhancing the domestic investment plays a vital role in achieving economic growth. Gross fixed capital formation GFCF (\% of GDP) is employed to measure the development of domestic investment (and some studies used it as infrastructure development proxy). The expected effect of the domestic investment on FDI is to be positive.

\subsection{Institutional Quality Variables}

As mentioned above, economic reforms and FDI policies are essential in terms of encouraging FDI, but these policies and reforms will not be enough without the existence of a healthy institutional environment to facilitate the exchange and increase confidence between economic players and reduce transactional cost. The presence of good institutional quality depends on the quality of its rules and providing a clear legal framework to govern 
the activities of direct investment, which is an important factor for the success of the foreign investment (Bevan \& Estrin 2004). In this context, corruption control is seen as one of the prominent institutional factors that reflect the quality of the country's institutional environment. Several studies including Wei (2000), Kwok and Tadesse (2006), Sayan (2009) concluded that there is a negative relationship between corruption level in the host country and FDI inflows. Also, foreign investors, generally try to avoid investing in corrupt countries. However, some empirical studies including Egger and Winner (2005), Biesenbender and Tosun (2014), to cite a few, argue that corruption is a stimulus for FDI, and corruption can have a positive impact on investment by facilitating transactions in countries with excessive regulation. This study employs the Corruption Perception Index (CPI) to measure the institutional quality.

\subsection{Political Instability Variables}

Political instability is considered as one of the bugbears that hinders the attraction of FDI in developing countries. Certainly, increases in political risk would reduce the certainty of the investment environment in the host country and make the investment climate and economic outcome very unpredictable. Studies by Dupasquier and Osakwe (2006), and Kim (2010) concluded that political instability is a prominent reason that has been responsible for the low inward FDI. However, some studies including Asiedu (2002) Kandiero and Chitiga (2006) concluded that political instability and absence of political rights in a country are not significant in influencing FDI. This study uses the Political Constraints Index (POLCON) which measures the extent of change in political actors and its influence on government policies and reforms. The expected sign of political instability's effect on FDI inflows is negative.

\subsection{FDI Policies}

These types of policies can directly affect a foreign firm's decision, where these policies aim to reduce the transaction cost of foreign companies entering the economy, regulate the flow of FDI. In addition to the creation of incentives and restrictions on operations work at the domestic and international level.

International FDI Policies: this type of policy targets the enhancement FDI through signing agreements and treaties with other regions or countries, and these agreements include improving the main terms and condition that control the investment activities between countries. The first type of these agreements is Bilateral Investment Treaties (BIT) that target the regulation of investment operations by means of laying down specific standards of investment protection and transfer of funds. The second type of these agreements is Regional Investment Agreements (RIA). According to OECD (2010), regional investment 
agreements (RIAs) help attract more foreign investment through participation in ensuring a stable, predictable and transparent regulatory framework for international investment. Furthermore, they enhance the deployment framework for FDI, strengthen and facilitate cooperation between the host country and international investors in the investment fields, and reduce the gaps between national and international investment policies. Finally, Double Taxation Agreements (DTAs), which are defined as an agreement between two countries that reduce the tax bill for a foreign investor. These agreements seek to prevent the taxpayer from paying tax to both countries. Several studies including Buss et al. (2010), Berger et al (2013), Buthe and Milner (2014) found that these kinds of agreements can be considered as one of the elements of institutional reforms that foster the FDI inflow. This study uses the accumulated number of the countries that have in-force international investment agreements including (Bilateral Investment Treaties, Treaties with Investment Provisions, and Double Taxation Agreement) with the host country to measure the international FDI - Policies. The expected sign of the estimated coefficient of investment international agreements with FDI inflows is positive.

Domestic Investment Policies: these policies mainly aim to eliminate admission and establishment restrictions such as closing specific sectors or activities to foreign firms and minimize the ownership and control restrictions and remove any obstacles that hinder investments after entry such as constraints on employment of foreign labor and skilled manpower (Duarte et al,2017).

Many studies including Banga (2003) Zhao (2013) concluded that these policies had caused a rapid and steep increase in FDI and therefore, wage increase, and job opportunities decrease. The study will use the Business Freedom Index which measures the host county's investment openness, and this index refers to ease of starting, operating, and closing a business.

\section{Empirical Strategy}

North Africa region is considered one of the wealthiest areas regarding natural resources and geographic location, but the performance of FDI attractiveness is still weak and needs more effort. Thus, this paper employs a panel data estimation on a sample of Five North Africa countries (Algeria, Egypt, Libya, Morocco, and Tunisia) over the period 1996-2013. To examine the determinants of FDI inflows and impact of FDI-policies that are adopted by the host countries (North African countries) to encourage the inward foreign direct investment.

The choice of these years is attributed to data availability due to a shortage of this latter especially the one related to Algeria and Libya. In terms of selection of variables, it based on 
the empirical work of most researchers, which is also appropriate for this study. The variables have been categorized into different classifications according to their effect on FDI inflows as follows: economic variables, institutional variables, and political variables, with two kinds of investment policies that may have direct effects on FDI (Domestic FDI policies, and International FDI policies). The specification of the regression model used in this study can be outlined as follows:

$$
\begin{aligned}
\text { LnFDIstock }=\alpha & +\beta 1 \text { Investment agreement }+\beta 2 \text { investment freedom }+\beta 3 \text { LnMarket size } \\
& +\beta 4 \text { Trade oppeness }+\beta 5 \text { Naturl }+\beta 6 \mathrm{GFCF}+\beta \text { Infrastracture }+\beta \text { Inflation }+\beta 9 \mathrm{FX} \\
& +\beta 10 \text { Corruption }+\beta 11 \text { Regulation }+\beta 12 \text { Politcal }+\gamma \mathrm{ti}+\text { cit },
\end{aligned}
$$

\subsection{Data definition and Sources.}

Empirically, there are several methods used to measure the FDI inflows, and there is no consensus on a particular way. For example, many studies such as Adhikary (2010), Bhavan and Zhong (2011) Boubakri et al (2013) used net FDI inflows as a percentage of GDP. While Balakrishnan et al (2013) mentioned that using net FDI inflows as a percentage of GDP is not desirable in transition economies because of its high sensitivity to changes in a location's characteristics. Furthermore, they concluded that using the FDI relative GDP creates a problem with dependency and accuracy, where small states dominate the top ten FDI recipients and it is hard to distinguish the effect of explanatory variables on FDI.

On the other hand, many studies including Busse et al. (2010), Goodspeed et al. (2011), Barassi and Zhou (2012), Estrin and Uvalic (2014) used the total FDI stock as a measurement of FDI within a country. This measurement refers to the value of the share of affiliates' capital and reserves (including retained profits) attributable to the parent enterprise, plus the net indebtedness of subsidiaries to the parent enterprises. According to Estrin and Uvalic (2014) using the FDI stock is desirable because it is always positive, and hence natural log transformation does not usher into a loss of information in this variable. Moreover, it is mentioned that using the FDI stock is more appropriate for the transition and unstable economics. Thus, this study utilizes the natural logarithm value of total inward FDI stock. 
Table1: Data definition and Sources.

\begin{tabular}{|c|c|c|}
\hline Variable & Description & Source \\
\hline LnFDIstock & The natural logarithm of total inward FDI stocks. & UNCTAD \\
\hline Ln Market size & Real Gross domestic product in US\$ (Natural Log) & UNCTAD \\
\hline Trade openness & The ratio of export plus import over GDP & UNCTAD \\
\hline Natural resources & $\begin{array}{l}=1 \text { if the natural resource rents are more than } 10 \% \text { of GDP. } \\
\text { "Total natural resources rents are the sum of oil rents, natural gas rents, } \\
\text { coal rents (hard and soft), mineral rents, and forest rents." }\end{array}$ & World Bank \\
\hline $\begin{array}{l}\text { Investment } \\
\text { agreements }\end{array}$ & $\begin{array}{l}\text { Accumulated number of the countries that have in force international } \\
\text { investment agreements including (Bilateral Investment Treaties, Treaties } \\
\text { with Investment Provisions, and Double Taxation Agreement) with host } \\
\text { country. }\end{array}$ & UNCTAD \\
\hline $\begin{array}{r}\text { Investment } \\
\text { freedom }\end{array}$ & Average index of business freedom, finance freedom, tax freedom, & $\begin{array}{r}\text { Heritage } \\
\text { Foundation }\end{array}$ \\
\hline Infrastructure & $\begin{array}{l}\text { Electric power transmission and distribution losses (\% of output) "its } \\
\text { include losses in transmission between sources of supply and points of } \\
\text { distribution and in the distribution to consumers, including pilferage". }\end{array}$ & World Bank \\
\hline GFCF & $\begin{array}{l}\text { Gross fixed capital formation GFCF (\% of GDP), this measurement } \\
\text { reflects the government investments in terms of infrastructure } \\
\text { improvements such as constructing roads and railways, building hospitals } \\
\text { and schools as well as houses and industrial buildings. }\end{array}$ & IMF \\
\hline FX & Exchange Rate Stability Index ${ }^{1}$. & $\begin{array}{r}\text { The Trilemma } \\
\text { Indexes }\end{array}$ \\
\hline Inflation & The annual percentage change in consumer price index (CPI) & IMF \\
\hline Regulation & $\begin{array}{r}\text { Regulatory quality index, reflects the ability of the government to } \\
\text { formulate and implement sound policies and regulations that permit and } \\
\text { promote private sector development. }\end{array}$ & $\begin{array}{r}\text { World } \\
\text { Governance } \\
\text { indicators }\end{array}$ \\
\hline Corruption & Corruption Perception Index & $\begin{array}{r}\text { Transparency } \\
\text { International } \\
\text { Dataset }\end{array}$ \\
\hline \multirow[t]{2}{*}{ Political } & Political Constraints Index (POLCON) & $\begin{array}{r}\text { Henisz, Witold J. } \\
2002\end{array}$ \\
\hline & & $\begin{array}{r}\text { Based on Polity } \\
\text { IV, }\end{array}$ \\
\hline
\end{tabular}

\subsection{Pre- Estimation Tests Results}

As a first step in any econometric analysis, we examined the stationarity of the variables that are used in the model. This test aims to ensure that the variables are integrated, where non-stationary series could generate spurious regression results. In that context, there are numerous unit root tests for panel data and this study used the Levin-Lin-Chu test (LLC), Breitung test, Hadri Lm test,and Pearsan test that assumes homogeneity in the dynamics of the autoregressive coefficients for all cross-section data (series) (Aziz,2016). Table 2 shows that the series are stationary at first differences.

\footnotetext{
1 It indicates an annual standard deviation of the monthly exchange rate between the home country and the base
} country. The study used this proxy instead of real exchange rates due to the data limitation in these countries. 
Table 2 : Panel Unit Root Tests ( $1^{\text {st }}$ differences).

\begin{tabular}{llllll}
\hline Variable & $\begin{array}{l}\text { LLC Test } \\
\mathrm{H}_{\mathrm{o}} \text { : Panels } \\
\text { contain unit } \\
\text { roots }\end{array}$ & $\begin{array}{l}\text { Breitung Test } \\
\mathrm{H}_{\mathrm{o}} \text { : Panels } \\
\text { contain unit } \\
\text { roots }\end{array}$ & $\begin{array}{l}\text { Hadri LM test } \\
\mathrm{H}_{\mathrm{o}} \text { : All panels are } \\
\text { stationary }\end{array}$ & $\begin{array}{l}\text { Pearsan test (xtcips) } \\
\mathrm{H}_{\mathrm{o}} \text { : non-stationary } \\
\left(\mathrm{T}_{\text {cips }}>\mathrm{T}_{\text {critical }}\right)\end{array}$ \\
\cline { 5 - 6 } & & & & T critical $1 \%$ \\
\hline LnFDIstock & $(0.0319)$ & $(0.0468)$ & $(0.1047)$ & -4.248 & -3.46 \\
Investment agreements & $(0.0000)$ & $(0.0000)$ & $(0.4328)$ & -4.346 & -3.20 \\
Investment free & $(0.0000)$ & $(0.0000)$ & $(0.8649)$ & -5.046 & -3.46 \\
LnMarket & $(0.5065)$ & $(0.0284)$ & $(0.9541)$ & -4.663 & -3.20 \\
Trade openness & $(0.0030)$ & $(0.0434)$ & $(0.5799)$ & -4.305 & -3.46 \\
GFCF & $(0.0000)$ & $(0.0001)$ & $(0.4110)$ & -4.398 & -3.46 \\
infrastructure & $(0.0154)$ & $(0.0000)$ & $(0.9109)$ & -5.506 & -3.20 \\
Inflation & $(0.0000)$ & $(0.0027)$ & $(0.9764)$ & -4.893 & -3.20 \\
Fx & $(0.0000)$ & $(0.0000)$ & $(0.9348)$ & -4.362 & -3.20 \\
Corruption & $(0.0000)$ & $(0.0000)$ & $(0.7282)$ & -4.725 & -3.20 \\
Regulation & $(0.0000)$ & $(0.0000)$ & $(0.4644)$ & -4.640 & -3.20 \\
Poltical & $(0.0001)$ & $(0.0551)$ & $(0.7306)$ & -3.027 & -3.20 \\
\hline
\end{tabular}

Notes : -

- all tests in constant with the time trend

- In LLC test ( demean is used ) to control the effect of cross-sectional means.

- For Breitung and Hadri LM test (controlled the effect of cross-sectional means and allowed cross-sectional dependence).

- For Parson (xtcips) test ( controlled the effect of cross-sectional dependence)

Before employing estimations, we also conducted specific pre-estimation tests: we made sure that there was no multicollinearity among the variables included in the models, where the mean Variance Inflation Factor (VIF) of 1.24.and based of correlation matrix between the variables, the correlation among variables was less than 0.5. (See tables 3.and 4)

The Breusch-Pagan test displays that the p-value is 0.240 which indicates that there is no heteroscedasticity, and Hausman tests revealed that 'Random effects' specification was the appropriate model for estimations. Based on the result of the Wooldridge test (Wooldridge, 2002; Drukker, 2003) for autocorrelation, which indicated that the Prob $>F=0.1165$. Hence, our model is not affected by the first-order autocorrelation.

Moreover, according to the Freidman test of cross-sectional independence, the p-value was 0.0020 , and this amount is smaller than 0.05 . Therefore, we reject a null hypothesis, which means that there is cross-sectional dependence

Hence, ignoring cross-sectional correlation would lead to severely biased results (Hoechle, 2007). Thus, we employ Driscoll and Kraay (1998)'s standard error correction method (labeled as 'scc', as in spatial correlation consistent) in our estimations, in order to simultaneously deal with cross-sectional dependence (which also deal with serial correlation and heteroskedasticity). 
Table 3: Partial correlation VIF test.

\begin{tabular}{lll}
\hline Variable & VIF & $\mathbf{1 / V I F}$ \\
\hline$\Delta$ Trade openness & 1.50 & 0.668615 \\
Inflation $(\Delta$ CPI $)$ & 1.44 & 0.692557 \\
$\Delta$ LnMarket & 1.41 & 0.706782 \\
Natural resourse.D & 1.31 & 0.760468 \\
$\Delta$ Regulation & 1.29 & 0.774447 \\
$\Delta$ Infrastructure & 1.21 & 0.829762 \\
$\Delta$ Political & 1.19 & 0.842960 \\
$\Delta$ Corruption & 1.16 & 0.861560 \\
$\Delta$ Investment agreements & 1.15 & 0.722000 \\
$\Delta$ GCF & 1.12 & 0.889518 \\
$\Delta$ investment freedom & 1.08 & 0.922233 \\
$\Delta$ Fx & 1.07 & 0.935123 \\
Mean VIF 1.24 & & \\
\hline
\end{tabular}

\section{Results and Conclusion}

Several previous studies dealt with three main driving factors of FDI in host countries which are market factors, resource factors and efficiency seeking factors (Dunning, 1988). This study attempted to investigate the impact of macroeconomic and role of domestic and international FDI policies in attracting FDI. Thus, the findings of this paper are instrumental for policymakers in North African countries in a way that helps governments make a well justified and more informed decision about how they can encourage and attract foreign direct investment and determine which investment policies are suitable according to current and future predictions (see tables 5 and 6).

This study found a positive and significant relationship between investment freedom variable and groth FDI in host countries at the $1 \%$ level, which implies that foreign firms prefer to expand their activities within less restrictive business environments and, enhancement of investment conditions may attract more foreign investors to the North African region. The coefficient of trade openness is positive and significant at the $5 \%$ level with change of FDI inflows.

Therefore, promoting integration into global trade, and country liberalization toward international trade leads to more polarization of FDI to that region, and foreign investors prefer investing in countries with sizeable trade volume. With regard to the natural resources effect, the results showed that the natural resources dummy has a negative and insignificant relationship with change of FDI inflows. This could be the result of state strong hold over of the oil sector especially in Algeria and Libya. Moreover, the insignificant relationship of natural resources might be a result of considerable variation in North African countries concerning natural resources reserves. However, this should not be necessarily interpreted as evidence of the absence of a relationship between this and other measures and economic outcomes. 


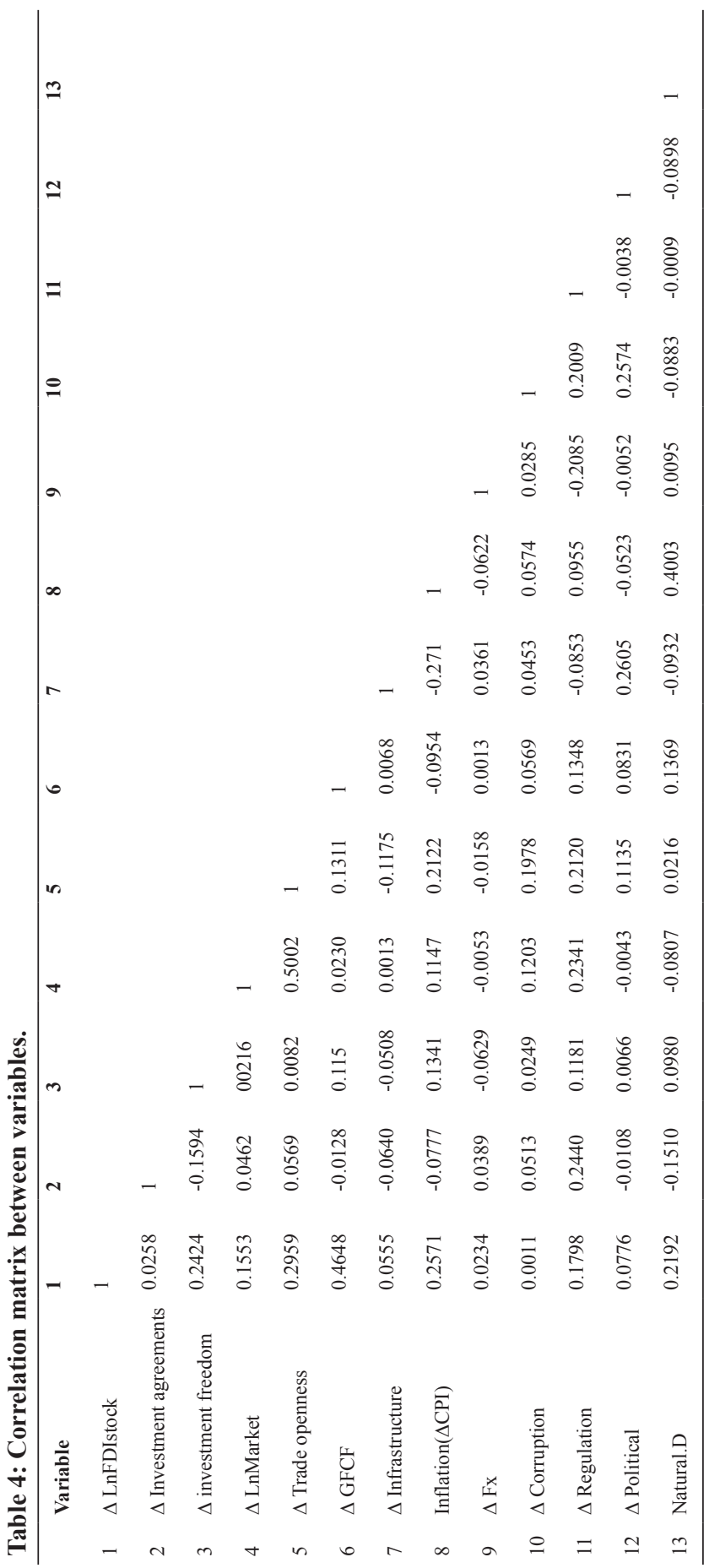




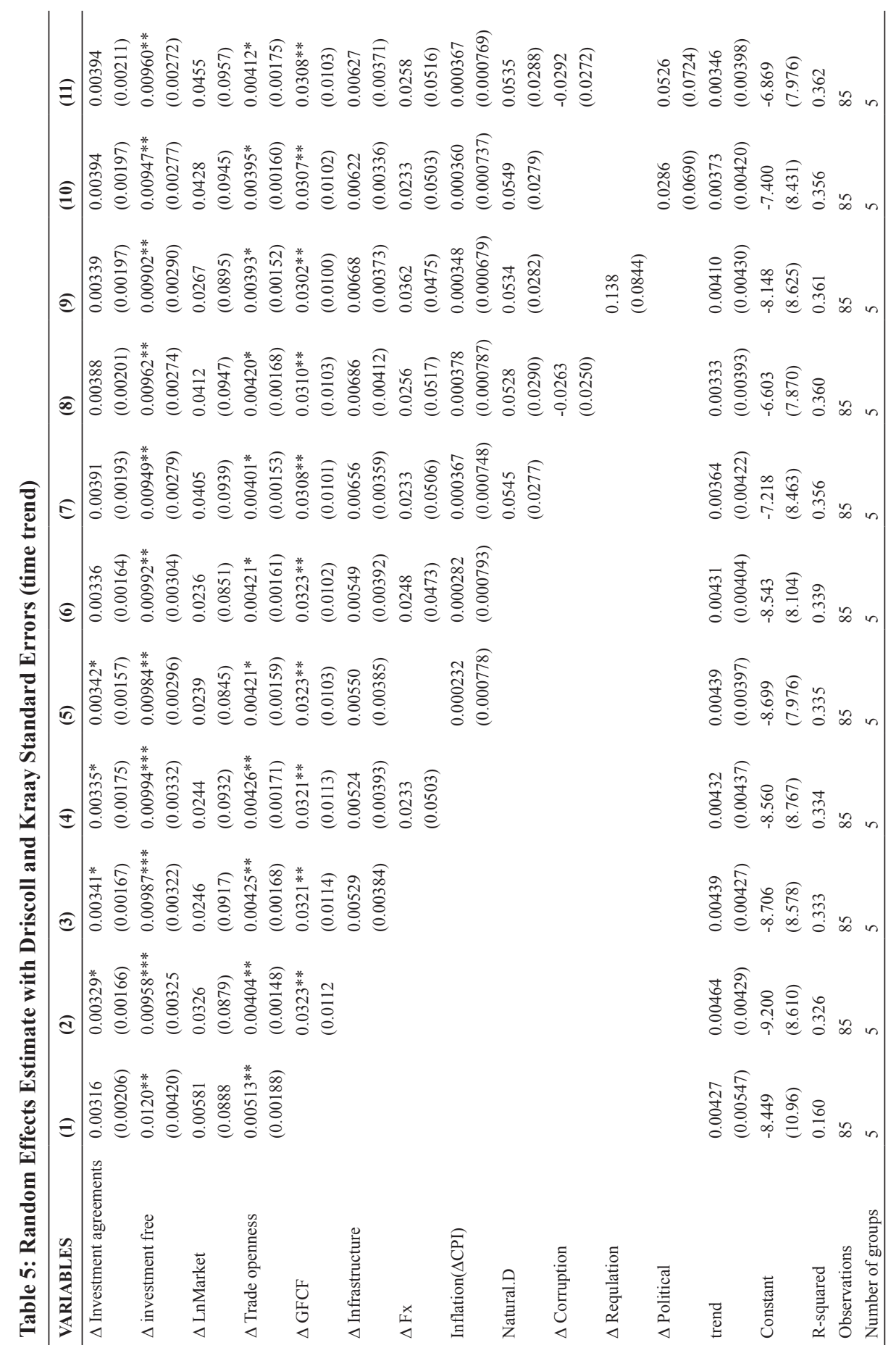




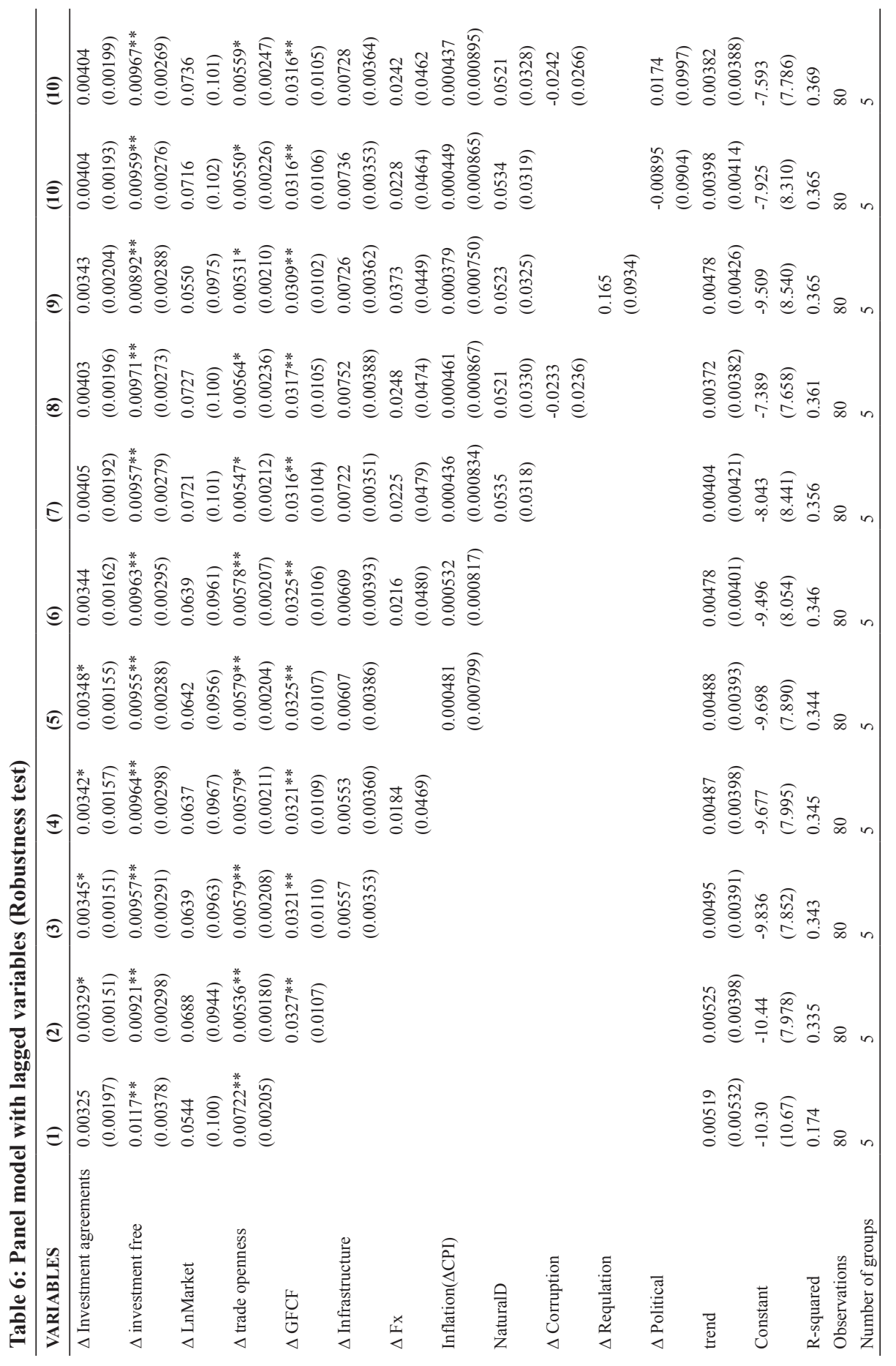


The domestic investment variables relation is positive and significant, which indicates that enhancing the volume of local investment including constructing roads and railways, building hospitals and schools as well as houses and industrial buildings reflected putatively on the FDI in North African countries. Regarding institutional quality, the investment profile variable is positive and significant, and this finding proves that the investment conditions attract more foreign firms in this region. However, market size was found to have an insignificant relationship with the growth of FDI. This is likely due to the region's fragility in terms of market size, or it might be the result of insufficient variation in the data to detect a statistical relationship. In terms of institutional quality, the findings illustrate that corruption in North African countries has a negative but insignificant coefficient.

In sum FDI inwards to the North Africa region has notably increased in the last twenty years but it still looks weak compared to other developing countries. The current paper examined the role of investment policies and determinant of FDI flows to North African countries. The results of our model showed that the ease of doing investment and business and establishment procedures have a positive impact on FDI attractiveness. Therefore, the enhancement of investment conditions may attract more foreign investors to the North Africa region. Furthermore, the country liberalization toward international trade leads to more polarization of FDI in that region. As for examining the effect of corruption on the growth of FDI inflow, the findings also illustrate that corruption in North Africa countries have a negative but insignificant coefficient. This might be attributed to insufficient variation in data used to detect a statistical relationship. Regarding the effect of market size, the findings show that the growth of real GDP doesn't have a strong statistical relationship with the growth of FDI. The results also revealed that the enhancement of the domestic investments could make the investment conditions in North Africa countries more attractive to foreign firms, and therefore, policymakers in this region should focus on infrastructure investments and allocate more resources for projects that may promote it.

Peer-review: Externally peer-reviewed.

Conflict of Interest: The authors have no conflict of interest to declare.

Grant Support: The authors declared that this study has received no financial support.

\section{References}

Abbott, A., Cushman, D. O., \& De Vita, G. (2012). Exchange rate regimes and foreign direct investment flows to developing countries. Review of international economics, 20(1), 95-107.

Adhikary, B. K. (2010). FDI, trade openness, capital formation, and economic growth in Bangladesh: a linkage analysis. International Journal of Business and Management, 6(1), 16.

Aizenman, J., Chinn. M. D., and Ito, Hiro (2013). "The 'impossible trinity' hypothesis in an era of global imbalances: Measurement and testing. Review of International Economics, 21(3), 447-458. 
Arab Investment \& Export Credit Guarantee Corporation (DHAMAN). (2014). FDI in Arab countries according to geographical distribution and enterprises, Quarterly Bulletin. Kuwait. Retrieved from http://dhaman.net/ar/ research-studies/investment-climate-report-latest/

Asghar, N., Nasreen, S., \& Rehman, H. (2011). Relationship between FDI and economic growth in selected Asian countries: A panel data analysis. Review of Economics \& Finance, 2, 84-96.

Asiedu, E. (2002). On the determinants of foreign direct investment to developing countries: is Africa different? World development, 30(1), 107-119.

Asiedu, E. (2006). Foreign direct investment in Africa: The role of natural resources, market size, government policy, institutions and political instability. The World Economy, 29(1), 63-77.

Asiedu. (2004). Policy Reform and Foreign Direct Investment in Africa: Absolute Progress but Relative Decline. Development Policy Review, 41-48.

Aziz, O. G., \& Mishra, A. V. (2016). Determinants of FDI inflows to Arab economies. The Journal of International Trade \& Economic Development, 25(3), 325-356.

Balakrishnan, M. S., Muhammad, N., Sikdar, A., Rogmans, T., \& Ebbers, H. (2013). The determinants of foreign direct investment in the Middle East North Africa region. International Journal of Emerging Markets.

Banerjee, S. G., Oetzel, J. M., \& Ranganathan, R. (2006). Private provision of infrastructure in emerging markets: do institutions matter? Development Policy Review, 24(2), 175-202.

Banga, R. (2003). Impact of government policies and investment agreements on FDI inflows. Indian Council for Research on International Economic Relations, 1-43.

Barassi, M. R., \& Zhou, Y. (2012). The effect of corruption on FDI: a parametric and non-parametric analysis. European Journal of Political Economy, 28(3), 302-312.

Biesenbender, S., \& Tosun, J. (2014). Domestic politics and the diffusion of international policy innovations: How does accommodation happen? Global Environmental Change, 29, 424-433.

Bellak, C., Leibrecht, M., \& Damijan, J. P. (2009). Infrastructure endowment and corporate income taxes as determinants of foreign direct investment in Central and Eastern European countries. The World Economy, 32(2), 267-290.

Berger, A., Busse, M., Nunnenkamp, P., \& Roy, M. (2013). Do trade and investment agreements lead to more FDI? Accounting for key provisions inside the black box. International Economics and Economic Policy, 10(2), $247-275$.

Bevan, A. A., \& Estrin, S. (2004). The determinants of foreign direct investment into European transition economies. Journal of Comparative Economics, 32(4), 775-787.

Bhavan, T., Xu, C., \& Zhong, C. (2011). Determinants and growth effect of FDI in South Asian economies: Evidence from a panel data analysis. International Business Research, 4(1), 43.

Bilel, K., \& Mouldi, D. (2011). The relationship between financial liberalization, FDI and economic growth: An empirical test for MENA countries. Economics and Finance Review, 1, 20-26.

Boateng, A., Hua, X., Nisar, S., \& Wu, J. (2015). Examining the determinants of inward FDI: Evidence from Norway. Economic Modelling, 47, 118-127.

Boubakri, N., Cosset, J. C., Debab, N., \& Valéry, P. (2013). Privatization and globalization: An empirical analysis. Journal of Banking \& Finance, 37(6), 1898-1914.

Buettner, T., \& Ruf, M. (2007). Tax incentives and the location of FDI: Evidence from a panel of German multinationals. International Tax and Public Finance, 14(2), 151-164.

Busse, M., Königer, J., \& Nunnenkamp, P. (2010). FDI promotion through bilateral investment treaties: more than a bit? Review of World Economics, 146(1), 147-177.

Buthe, T., \& Milner, H. V. (2014). The politics of foreign direct investment into developing countries: increasing FDI through international trade agreements? American Journal of Political Science, 52(4), 741-762. 
Choi, J. J., Lee, S. M., \& Shoham, A. (2016). The effects of institutional distance on FDI inflow: General environmental institutions (GEI) versus minority investor protection institutions (MIP). International Business Review, 25(1), 114-123.

Dash, R. K., \& Sahoo, P. (2010). Economic growth in India: the role of physical and social infrastructure. Journal of Economic Policy Reform, 13(4), 373-385.

Drukker, D. M. (2003). Testing for serial correlation in linear panel-data models. The Stata journal, 3(2), $168-177$.

Duarte, L. D. R. V., Kedong, Y., \& Xuemei, L. (2017). The Relationship between FDI, Economic Growth and Financial Development in Cabo Verde. International Journal of Economics and Finance, 9(5), 132.

Dunning, J. H. (1988). The theory of international production. The International Trade Journal, 3(1), 21-66.

Dunning, J. H. (1993). Internationalizing Porter's diamond. Management International Review, 33(2),

Dunning, J. H. (2002). Global Capitalism, FDI and competitiveness (Vol. 2). Edward Elgar Publishing.

Dupasquier, C., \& Osakwe, P. N. (2006). Foreign direct investment in Africa: Performance, challenges, and responsibilities. Journal of Asian Economics, 17(2), 241-260.

Egger, P., \& Winner, H. (2005). Evidence on corruption as an incentive for foreign direct investment. European Journal of Political Economy, 21(4), 932-952.

Estrin, S., \& Uvalic, M. (2014). FDI into transition economies: are the Balkans different? Economics of Transition, $22(2), 281-312$.

Feeny, S., Iamsiraroj, S., \& McGillivray, M. (2014). Growth and foreign direct investment in the Pacific Island countries. Economic Modelling, 37, 332-339.

Goodspeed, T., Martinez-Vazquez, J., \& Zhang, L. (2011). Public policies and FDI location: Differences between developing and developed countries. FinanzArchiv: Public Finance Analysis, 67(2), 171-191.

Guris, S., \& Gozgor, K. (2015). Trade Openness and FDI Inflows in Turkey. Applied Econometrics and International Development, 15(2), 53-62.

Hailu, Z. A. (2010). Demand side factors affecting the inflow of foreign direct investment to African countries: does capital market matter? International Journal of Business and Management, 5(5), 104.

Henisz, W. J. (2002). The political constraint index (POLCON) dataset. University of Pennsylvania, Wharton School. Retrieved from https://mgmt.wharton.upenn.edu/faculty/heniszpolcon/polcondataset/

Heritage Foundation (2019). The index of economic freedom. Washington, D.C: Heritage Foundation. Retrieved from https://www.heritage.org/index/explore

Hoechle, D. (2007). Robust standard errors for panel regressions with cross-sectional dependence. The stata journal, 7(3), 281-312.

IMF, (2019) "Consumer price index, and gross fixed capital formation data" Washington, D. C. International Monetary Fund. Retrieved from https://www.imf.org/external/datamapper/PCPIPCH@WEO/OEMDC/

Kandiero, T., \& Chitiga, M. (2006). Trade openness and foreign direct investment in Africa: economics. South African Journal of Economic and Management Sciences, 9(3), 355-370.

Kaur, M., Khatua, A., \& Yadav, S. S. (2016). Infrastructure development and FDI inflow to developing economies: Evidence from India. International Business Review, 58(6), 555-563.

Kim, H. (2010). Political stability and foreign direct investment. International Journal of Economics and Finance, 2(3), 59-71.

Kwok, C. C., \& Tadesse, S. (2006). The MNC as an agent of change for host-country institutions: FDI and corruption. Journal of International Business Studies, 37(6), 767-785.

Laabas, B., \& Abdmoulah, W. (2009). Determinants of Arab intraregional foreign direct investments. Journal of Business \& Policy Research, 4(2), 138-169. 
Mah, J. S. (2010). Foreign direct investment inflows and economic growth of China. Journal of Policy Modeling, $32(1), 155-158$.

Marc, A. (2011). Is foreign direct investment a cure for economic growth in developing countries? Structural model estimation applied to the case of the south shore Mediterranean countries. Journal of International Business and Economics, 11(4), 32-51.

Mina, W. (2007). The location determinants of FDI in the GCC countries. Journal of Multinational Financial Management, 17(4), 336-348.

Mohamed, S. E., \& Sidiropoulos, M. G. (2010). Another look at the determinants of foreign direct investment in MENA countries: an empirical investigation. Journal of economic development, 35(2), 75.

Mottaleb, K. A., \& Kalirajan, K. (2010). Determinants of foreign direct investment in developing countries: A comparative analysis. Margin: The Journal of Applied Economic Research, 4(4), 369-404.

Factbook, O. E. C. D. (2010). Economic, Environmental and Social Statistics/Organization for Economic Cooperation and Development.

Onyeiwu, S., \& Shrestha, H. (2004). Determinants of foreign direct investment in Africa. Journal of Developing Societies, 20(1-2), 89-106.

Poelhekke, S., \& van der Ploeg, F. (2013). Do natural resources attract non-resource FDI? Review of Economics and Statistics, 95(3), 1047-1065.

Pradhan, R. P., Arvin, M. B., Hall, J. H., \& Nair, M. (2017). Trade openness, foreign direct investment, and financegrowth nexus in the Eurozone countries. The Journal of International Trade \& Economic Development, 26(3), $336-360$.

Sayan, S. (Ed.). (2009). Economic performance in the Middle East and North Africa: institutions, corruption and reform. Routledge.

Te Velde, D. W. (2001). Policies towards foreign direct investment in developing countries: emerging best-practices and outstanding issues. London: Overseas Development Institute, 1-34.

The World Bank, (2012). "World Development Indicators." Microdata Library. Retrieved from https://data. worldbank.org/

Transparency International (1996-2014). The Corruption Perception Index. Retrieved from http://www. transparency.org

UNCTAD, G. (2012). World investment report: Towards a new generation of investment policies. United Nations. New York and Geneva.

UNCTAD,2018, United Nations Conference on Trade and Development (UNCTAD) Handbook of Statistics. Retrieved from https://unctadstat.unctad.org/wds/TableViewer/tableView.aspx?ReportId=96

UNCTAD, 2019, World Investment Report. Promoting Linkages, (FDI stock data) United Nations, Geneva and New York. Retrieved from https://unctad.org/en/Pages/DIAE/World\%20Investment\%20Report/Annex-Tables.aspx

Wang, C., Hong, J., Kafouros, M., \& Wright, M. (2012). Exploring the role of government involvement in outward FDI from emerging economies. Journal of International Business Studies, 43(7), 655-676.

Wei, S. J. (2000). How taxing is corruption on international investors? Review of economics and statistics, 82(1), 1-11.

Wooldridge, J. M. (2003). Further results on instrumental variables estimation of average treatment effects in the correlated random coefficient model. Economics letters, 79(2), 185-191.

World Bank. (2011). Facing challenges and opportunities (Middle East and North Africa regional economic update). Washington DC, USA.

Worldwide Governance Indicators, (2018) The Worldwide Governance Indicators (WGI) project. Retrieved from https://info.worldbank.org/governance/wgi/Home/Reports 
United Nations Conference on Trade and Development. (2001). World investment report 2001: Promoting linkages. UN.

United Nations Conference on Trade and Development. (2013). World investment report 2013: Global value chains: Investment and trade for development. UN.

Yang, J. H., Wang, W., Wang, K. L., \& Yeh, C. Y. (2018). Capital intensity, natural resources, and institutional risk preferences in Chinese outward foreign direct investment. International Review of Economics \& Finance, 55, 259-272.

Yimer, A. (2017). Macroeconomic, political, and institutional determinants of FDI inflows to Ethiopia: An ARDL Approach. in studies on economic development and growth in selected African countries (pp. 123-151). Springer, Singapore.

Young, S., Hood, N., \& Hamill, J. (2017). Foreign multinationals and the British economy: Impact and policy. Routledge.

Zhao, S. (2013). Privatization, FDI inflow and economic growth: evidence from China's provinces, 1978-2008. Applied Economics, 45(15), 2127-2139. 